HUNGARIAN AGRICULTURAL ENGINEERING

$N^{\circ} 37 / 2020$ 48-52

Published online: http://hae-journals.org/

HU ISSN 0864-7410 (Print) / HU ISSN 2415-9751(Online)

DOI: 10.17676/HAE.2020.37.48

Received: 20.11.2019. - Accepted: 10.02.2020
PERIODICAL OF THE COMITTEE OF

AGRICULTURAL AND BIOSYSTEM

ENGINEERING OF

THE HUNGARIAN ACADEMY OF SCIENCES

and

SZENT ISTVÁN UNIVERSITY

Faculty of Mechanical Engineering

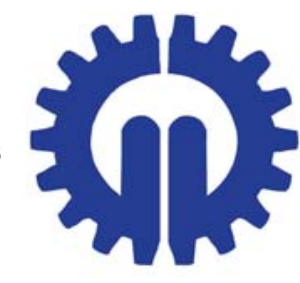

\title{
EFFECT OF REUSED ROCKWOOL SLABS ON THE PERFORMANCE OF 'DARAS F1' HOT PEPPER UNDER GLASSHOUSE CONDITIONS
}

\author{
Author(s): \\ A. Ombódi ${ }^{1}$ and M. B. Valkai \\ Affiliation: \\ ${ }^{1}$ Institute of Horticulture, Szent István University, Páter K. u. 1., Gödöllő, H-2100, Hungary \\ ${ }^{2}$ Szentesi Paradicsom Kft., Apponyi tér 12., Szentes, H-6600, Hungary \\ Email address: \\ ombodi.attila@mkk.szie.hu, valkaibencemark@gmail.com
}

\begin{abstract}
Reuse of rockwool slabs could improve sustainability of soilless cultivation. In this study effects of reused, two-year-old rockwool slabs on yield and quality of 'Daras F1' hot pepper hybrid was investigated, under commercial glasshouse conditions. Special attention was paid to anthocyanin discoloration disorder as the most important quality disorder of this pepper type. Total yield was the same, $15.26 \mathrm{~kg} \mathrm{~m}-2$, for both treatments, while weight ratio of fruits having anthocyanin discoloration was significantly less for reused slabs $(9 \%)$ than for the new ones $(13 \%)$. Possibly higher buffer capacity of reused slabs reduced salt induced osmotic stress causing lower rate of anthocyanin biosynthesis.
\end{abstract}

Keywords: anthocyanin discoloration, yield, slab electric conductivity, slab water content

\section{Introduction}

Soilless cultivation is gaining more and more ground in the Hungarian greenhouse industry and it has become the exclusively used production method for year-round glasshouse pepper crops (Szőriné Zielinska, 2019). Rockwool is one of the most popular substrates for soilless production worldwide (Sonneveld and Voogt, 2009) and in Hungary too (Slezák, 2019). Rockwool has excellent physical and chemical properties from the viewpoint of soilless production. However, after the cultivation, it often presents a waste material and an environmental concern, as it is difficult to recycle the rockwool slabs (Raviv et al., 2002). A possible solution for reducing the extent of this problem is to reuse the rockwool slabs for a second or for a third year. Beside the environmental concerns this practice also has some economic advantages, as cost of the substrates per growing season can be reduced. Use of rockwool slabs for two years instead of just one, enhances the sustainability of this high-tech production method. However, most of the growers are afraid of decreasing yield and inferior quality by employing reused rockwool slabs.

Reusing rockwool slabs for a second or third year induces changes in their physical properties. Water holding capacity of reused rockwool slabs is significantly higher, amount of their easily available water content is bigger and their air filled porosity is lower, compared to the new slabs. The changes are sometimes drastic; for example saturated hydraulic conductivity of new slabs was measured to be $17.3 \mathrm{~mm} \mathrm{~s}-1$ as opposed to 2.3 $\mathrm{mm} \mathrm{s}-1$ after just one year of usage. The pattern of water distribution within the slabs is also modified. Changes of physical characteristics starts at the bottom of the slabs, and later appearing in the upper parts too (Acuña \& Bonachela, 2005; Acuña et al, 2013). Urrestarazu and co-authors (2007) have explained these changes by the increased organic matter content of the reused slabs caused by the root remnants of the previous culture.

Anthocyanin discoloration is probably the most important quality problem of the Hungarian type hot pepper. The ratio of this disorder should be kept as low as possible, while sustaining high yield. The main anthocyanin component in pepper is delfinidin-3-kumaroil-rutinozid-5-glikozid (Liu, 2016, Kovács et al., 2017). Synthesis of this purplish colored component is genetically determined (Kovács et al., 2017). According to the local Hungarian observations, anthocyanin discoloration of fruits is mainly caused by insufficient phosphorus uptake, cold effect, low light level, high salt content of soil and/or irrigation water, insufficient water uptake. On the leaves this discoloration can be a result of a general stress effect (Ledóné, 2012; Ombódi and Terbe, 2019). Beside the phosphorus, deficiency of other nutrients, like nitrogen, boron, magnesium, sulphur and zinc, can also cause 
anthocyanin discoloration (Chalker-Scott, 2002). On the other hand, it was found for several different crops that high salt content induced osmotic stress resulted in higher rate of anthocyanin synthesis (Chalker-Scott, 1999).

The objective of this study was to investigate the effects of reused, two-year-old rockwool slabs compared to new ones on yield and quality of 'Daras F1' hot pepper hybrid, under commercial glasshouse conditions, with special reference to ratio of fruits having anthocyanin discoloration.

\section{Materials and methods}

The experiment was established in one of the glasshouses (46 40' 55.5" N 20 20' 04.9" E) of Árpád-Agrár Ltd., Szentes, Hungary, in a commercial hot pepper 'Daras F1' crop during the 2017/18 growing season. The glasshouse was built in 1977 and has an area of $10,500 \mathrm{~m} 2.1374 \mathrm{~J} \mathrm{~cm}-2$ was the average irradiation during this season. Climatic conditions were controlled by a Priva Intégro unit; air temperature was $20.2^{\circ} \mathrm{C}$, while relative humidity was $69 \%$ in the average of the whole growing period.

The pale-green coloured, Hungarian hot pepper type Daras F1 hybrid was used in the experiment. In its market segment it is the leading cultivar in Hungary, and have a berry size of $4 \mathrm{~cm}$ width and $20-22 \mathrm{~cm}$ length at maximum. Seeds were sown on the 2nd of October in 2017. Seedlings were raised in Grodan Delta rockwool cubes $(75 \times 75 \times 65 \mathrm{~mm})$ and were transplanted on the 6 th of November at 2.85 plants $\mathrm{m}-2$ density, corresponding to 5.7 stems $\mathrm{m}-2$. Plants were trained in a high-wire system and were pruned weekly leaving two stems on every plant. Fertigation was regulated by a Priva Intégro unit, minimum and maximum time between two irrigations and sum of irradiation for staring the next irrigation were set. Both treatments were fertigated with the same nutrient solution. Fruits were picked weekly until the beginning of June, and then at two-weeks intervals thereafter. The crop was terminated on the 8th of August in 2018.

Grodan Grotop Master 1575B1W (size: $1000 \times 150 \times 75 \mathrm{~mm}$ ) rockwool slabs were used in the experiment. After one year of use, slabs were disinfected with $2 \% \mathrm{v} v-1$ hydrogen-peroxide solution. New and reused, two-year-old slabs were compared. The experiment was set in the middle part of the house in one twin rows. One of the rows contained new slabs and the other reused ones. From both rows the middle 36 slabs were monitored for the experiment. Four replications were used, one replication was composed of 9 slabs, corresponding to 27 plants and $9.5 \mathrm{~m}^{2}$. Plants of the experiment were handled exactly the same way as the commercial plants of the house.

Climatic data were recorded continuously by the Priva Intégro unit. Water content, electric conductivity (EC) and temperature of the slabs of the commercial crop were recorded regularly throughout the whole growing season by Delta-T WET Kit device. These parameters were also measured hourly during three different days (06.03., 07.01., 07.29.) in the slabs of the experiment. The first measurement was performed before the first irrigation, and the last measurement after the last irrigation, in the middle of three different slabs of every repetition. Number and weight of the fruits and ratio of berries showing anthocyanin discoloration were recorded at every harvest. Similarly to the commercial crop, berries were graded into 10 different classes, two of them served for berries with anthocyanin discoloration (under and over $15 \mathrm{~cm}$ length).

Yield data were analysed by Student's two sample t-test in case of homoscedasticity or by Welch's t-test in case of heteroscedasticity. Correlation analysis was applied on the data to describe connection between slab water content and $\mathrm{EC}$ values of the slabs.

\section{Results}

Total yield of 'Daras F1' was completely the same, $15.26 \mathrm{~kg} \mathrm{~m}^{-2}$, either on new or on reused rockwool slabs. Hence, the employment of reused slabs did not decrease the yield of this hot pepper cultivar at all. The number of berries per plant also did not show significant difference between the treatments, it was 97 for the new and 94 for the reused slabs. Hence, average berry weight was slightly, but not significantly higher for reused slabs $(57 \mathrm{~g})$ than for new slabs $(55 \mathrm{~g})$. Statistically significant difference at $5 \%$ error level was also not found for ratio of number of berries classified as first, second and third class. However, ratio of the number of berries having anthocyanin discoloration was significantly lower for the reused slabs than for the new slabs (Table 1.). The same tendency could be observed for the weight ratio of these berries, it was $9.0 \%\left(1.36 \mathrm{~kg} \mathrm{~m}^{-2}\right)$ for the reused slabs and $4.0 \%$ more, $13.0 \%\left(1.99 \mathrm{~kg} \mathrm{~m}^{-2}\right)$ for the new slabs (Fig. 1.). 
Table 1. Quality distribution of berries of 'Daras F1' hot pepper plants grown on new or reused rockwool slabs

\begin{tabular}{|l|c|c|c|}
\hline \multicolumn{1}{|c|}{ Quality class } & New slabs & Reused slabs & P-value \\
\hline $1^{\text {st }}$ class $21 \mathrm{~cm}+$ & $5.8 \pm 0.4 \%$ & $6.2 \pm 0.4 \%$ & 0.3901 \\
\hline $1^{\text {st }}$ class $19 \mathrm{~cm}+$ & $16.5 \pm 0.3 \%$ & $18.3 \pm 1.1 \%$ & 0.1706 \\
\hline $1^{\text {st }}$ class $17 \mathrm{~cm}+$ & $19.6 \pm 0.7 \%$ & $21.2 \pm 0.6 \%$ & 0.1224 \\
\hline $1^{\text {st }}$ class $15 \mathrm{~cm}+$ & $9.4 \pm 1.1 \%$ & $8.2 \pm 0.1 \%$ & 0.3810 \\
\hline $2^{\text {nd }}$ class & $15.9 \pm 1.0 \%$ & $17.1 \pm 1.7 \%$ & 0.5703 \\
\hline $3^{\text {rd }}$ class & $18.6 \pm 0.8 \%$ & $19.0 \pm 0.3 \%$ & 0.6320 \\
\hline With anthocyanin discoloration & $14.2 \pm 1.0 \%$ & $10.0 \pm 1.1 \%$ & $\mathbf{0 . 0 2 7 1}$ \\
\hline
\end{tabular}

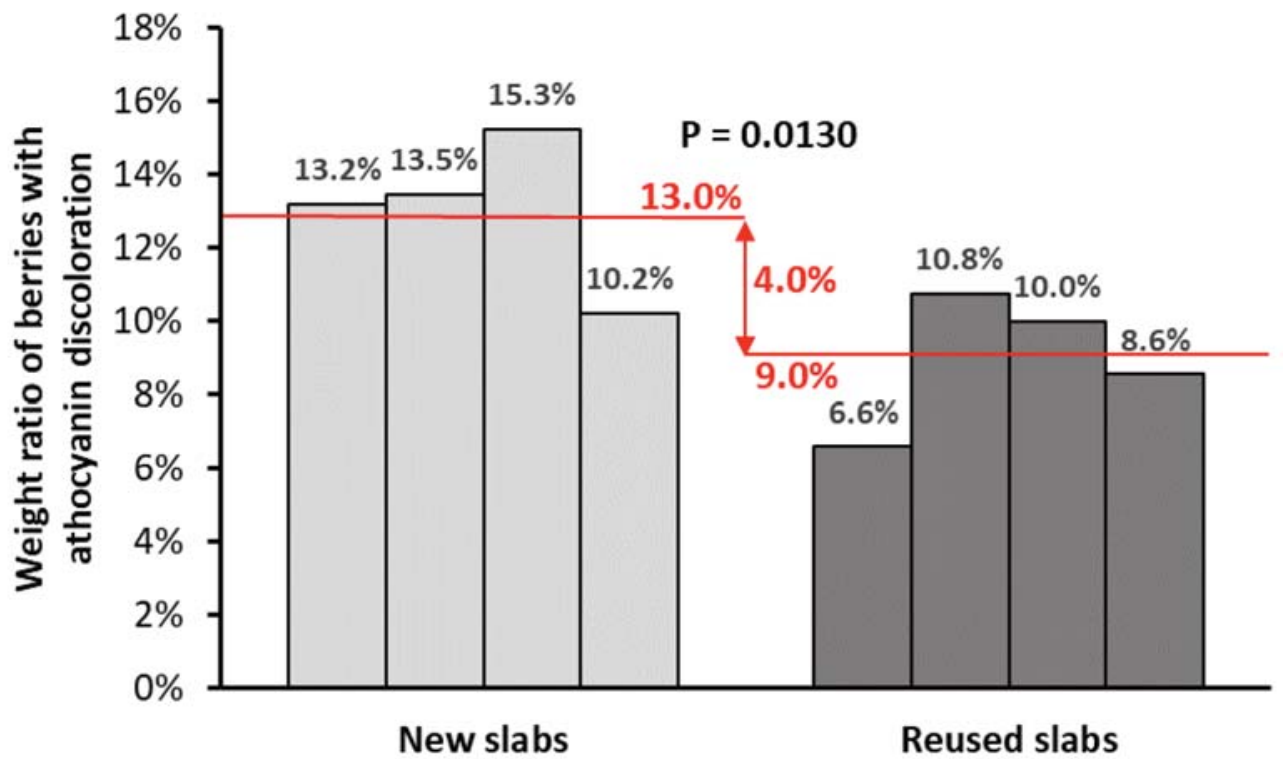

Figure 1. Weight ratio of berries with anthocyanin discoloration harvested from 'Daras F1' hot pepper grown on new or reused rockwool slabs

Analysis performed on the data of previous years of the commercial crop showed positive correlation between EC value of slabs and ratio of berries with anthocyanin discoloration. High EC results in salt stress which could trigger increased anthocyanin biosynthesis (Chalker-Scott, 2002). Analysis of the hourly slab characteristic measurement data showed much stronger correlation between EC and water content for the new slabs $(\mathrm{N}=384, \mathrm{r}=-0,3657, \mathrm{p}=1,35 \times 10-13)$ than for the reused slabs $(\mathrm{N}=384 ; \mathrm{r}=-0,1289 ; \mathrm{p}=0,0115)$. Regression analysis performed on these data proved that for new slabs, EC has increased in a twice-bigger extent as result of decreasing water content compared to the reused ones (Fig. 2.). The reason for this phenomenon could be the higher buffering capacity of the two-year-old slabs resulting from root remnants of the previous year's crop (Urrestarazu et al., 2007) (Fig. 2.). Significant correlation was not found between the temperature and the EC values of the slabs.

As described above, it was found that decrease of slab water content due to water consumption of the plants induced twice as high EC increase rate in the new slabs, than in the reused ones. Higher EC means higher salt content which after a certain level causes salt stress for the plants. The changed osmotic conditions in the 
roots could reduce the water and nutrient uptake rates. The stress effect also could activate genes which are responsible for anthocyanin synthesis (Chalker-Scott 1999, Kovács 2007). Hence, higher buffering capacity of the reused slabs decreased the extent of salt and osmotic stress resulting in lower level of anthocyanin synthesis. Based on these conclusions we can state that time intervals between irrigation could be a very important factor in the appearance and rate of fruits having anthocyanin discoloration disorder. It is advisable to base irrigation strategy of pepper cultivars sensitive to anthocyanin discoloration as much on slab EC value than on the usual climatic factors, like irradiation and temperature, and to irrigate more frequently.
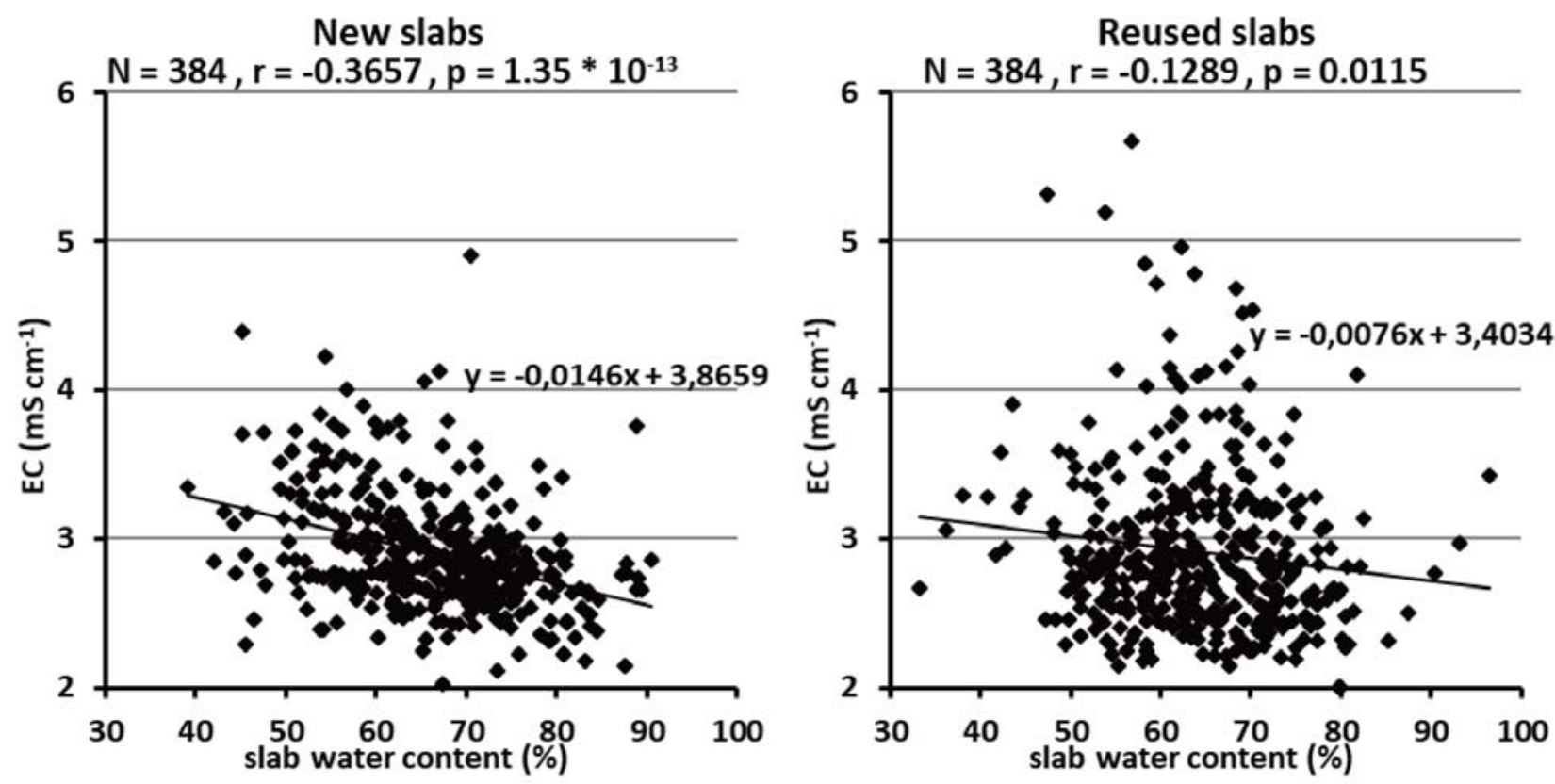

Figure 2. Correlation between water content and electric conductivity measured from new and reused rockwool slabs

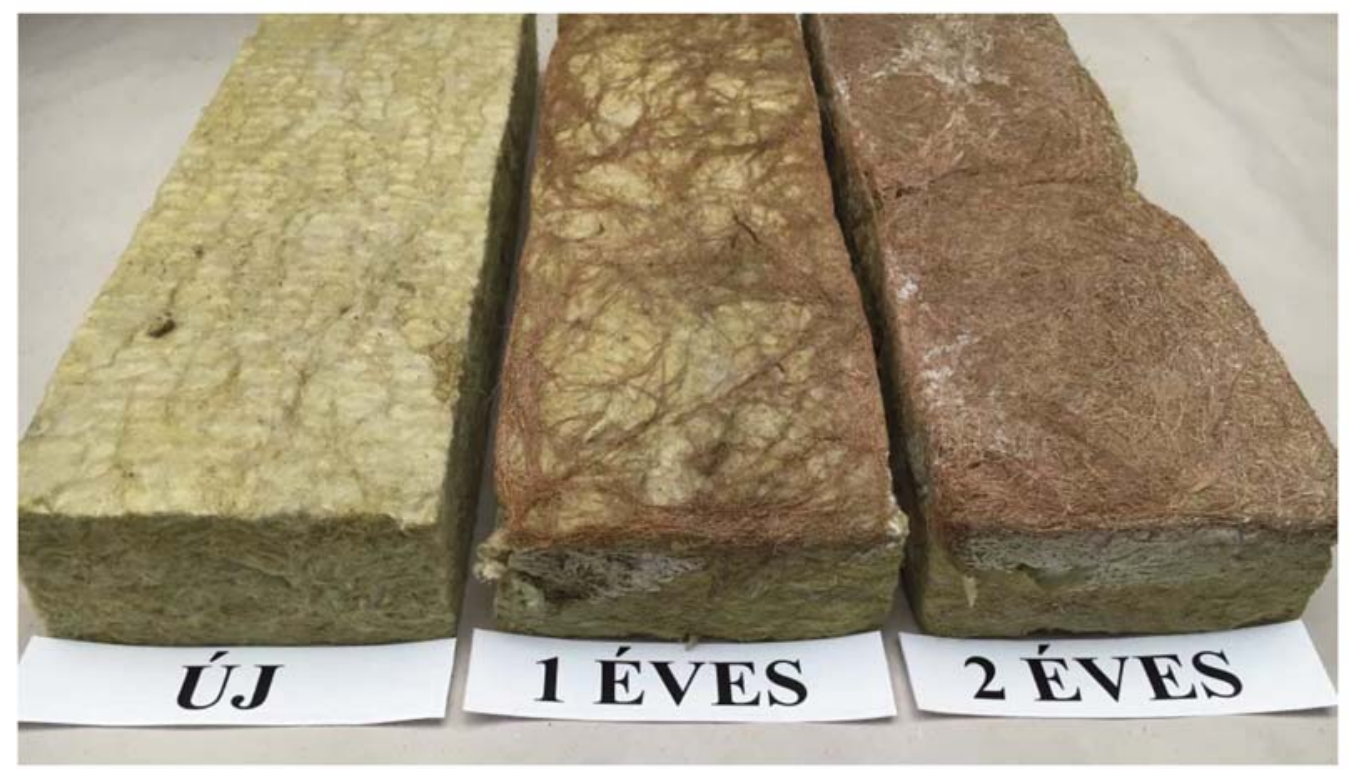

Figure 3. Rockwool slabs (upside down) from the experiment: before usage (left), after the first growing season (center), after two growing seasons (right) 


\section{Conclusions}

Based on our results we have concluded that use of reused, two-year-old rockwool slabs for cultivation of 'Daras F1' hot pepper not just that did not decrease the yield, but also significantly reduced the ratio of berries showing anthocyanin discoloration. Results of correlation analysis between slab water content and slab EC proved that reused slabs had bigger buffering capacity, possibly caused by higher organic matter content, originating from root remnants of the previous year's crop. Higher buffering capacity could reduce the effect of salt stress on the plants grown in the reused slabs, causing lower osmotic stress and as a result lower level of anthocyianin biosynthesis.

\section{Acknowledgements}

This publication has been completed within the framework of project no. EFOP-3.6.1- 16-2016-00016 focusing on training and research profiles with intelligent specializations on the Szarvas Campus of St Istvan University involving agricultural water management, hydroponic plant systems, alternative crop production related to improving precision machinery in agriculture.

\section{References}

[1] Acuña, R. and S. Bonachela (2005), Response of a sweet pepper crop grown in new and two-year-old reused rockwool slabs in greenhouse on the mediterranean coast of south-east Spain, Acta Horticulturae, Vol. 697, pp. 189-194.

[2] Acuña, R., S. Bonachela, J. J. Magán, O. Marfà, J. H. Hernández and R. Cáceres (2013), Reuse of rockwool slabs and perlite grow-bags in a low-cost greenhouse: Substrates' physical properties and crop production, Scientia Horticulturae, Vol. 160, pp. 139-147.

[3] Chalker-Scott, L. (1999), Environmental significance of anthocyanins in plant stress responses, Photochemistry and Photobiology, Vol. 70, pp. 1-9.

[4] Chalker-Scott, L. (2002), Do anthocyanins function as osmoregulators in leaf tissues?, Advances in Botanical Research, Vol. 37, pp. 103-127.

[5] Kovács, Zs., G. Csilléry, A. Szőke, E. Kiss and A. Veres (2017), Characteristics and regulation of anthocyanin biosynthesis in pepper - review, Columella Journal of Agricultural and Environmental Sciences, Vol. 4, pp. 47-58.

[6] Ledóné, D. H. (2012), A paprika „lilulásáról” [About the “purpling” of paprika], Zöldségkertész, Vol. 14, pp. 14.

[7] Liu, Y. (2016), Anthocyanin regulation in bell pepper fruit, MSc Thesis, Wageningen University, Wageningen.

[8] Ombódi, A. and I. Terbe (2019), A talaj nélküli termesztés fiziológiai alapjai [Physiological bases of soilless cultivation], In: I. Terbe and K. Slezák (Eds.), Talaj nélküli zöldséghajtatás [Soilless vegetable forcing], Mezőgazda Kiadó, Budapest.

[9] Raviv, M., R. Wallach, A. Silber and A. Bar-Tal (2002), Substrates and their analysis, In: D. Savvas and H. Passam (Eds.), Hydroponic production of vegetables and ornamentals, Embryo Publications, Athens.

[10] Sonneveld, C. and W. Voogt (2009), Nutrition of greenhouse horticulture, Springer, Doordrecht.

[11] Slezák, K. (2019), A talaj nélküli termesztésben használt közegek jellemzése [Characterisation of substrates used for soilless cultivation], In: I. Terbe and K. Slezák (Eds.), Talaj nélküli zöldséghajtatás [Soilless vegetable forcing], Mezőgazda Kiadó, Budapest.

[12] Szőriné Zielinska A. (2019), A paprika talajnélküli termesztése [Soilless cultivation of sweet pepper], In: I. Terbe and K. Slezák (Eds.), Talaj nélküli zöldséghajtatás [Soilless vegetable forcing], Mezőgazda Kiadó, Budapest.

[13] Urrestarazu, M., C. Guillén, C. Mazuela and G. Carrasco (2008), Wetting agent effect on physical properties of new and reused rockwool and coconut coir waste, Scientia Horticulturae, Vol. 116(1), pp 104108. 